\title{
Responding to COVID-19 With the Aid of Mutually Beneficial Partnerships in Education
}

\author{
Manuelito Biag ${ }^{1 *}$, Louis M. Gomez ${ }^{2,1}$, David G. Imig ${ }^{3,1}$ and Ash Vasudeva ${ }^{1}$ \\ ${ }^{1}$ Carnegie Foundation for the Advancement of Teaching, Stanford, CA, United States, ${ }^{2}$ UCLA Graduate School of Education and \\ Information Studies, Los Angeles, CA, United States, ${ }^{3}$ College of Education at the University of Maryland, College Park, College \\ Park, MD, United States
}

The COVID-19 pandemic has altered the structures and routines of K-12 education. Districts and school systems worldwide continue to adapt their ways of working to address a variety of challenges-many of whose dimensions are complex, dynamic, and not entirely known. Without cooperation and collaboration among stakeholders, institutions, and communities, we will be less able to address students' social, emotional, and learning needs. In this paper, we present evidence that suggests mutually beneficial partnerships between local education agencies (LEAs) and institutions of higher education (IHEs), grounded in improvement science, can serve as an essential resource to address dilemmas brought about by the pandemic. We examine the work of four partnerships in the Improvement Leadership Education and Development (iLEAD) Network. Our analysis suggests that what matters in this period of uncertainty is that partnerships take a systems perspective, pay direct attention to the needs of critical users, avoid pre-determined programs and solutions, and engage in disciplined inquiry across institutional boundaries to affect positive and lasting change. A deeper understanding of how these partnerships operate-their principles, routines, methods, and tools-can help educational systems support students during the current global health crisis.

Keywords: iLEAD, improvement science, boundary crossing, value creation, mutually beneficial partnerships

\section{INTRODUCTION}

Biological disasters are "natural scenarios involving disease, disability or death on a large scale among humans, animals and plants due to microorganisms like bacteria, or virus or toxins (Kumar, 2020, p. 6)." The COVID-19 pandemic qualifies as a biological disaster and it has spread worldwide. Unlike other recent disasters, biological and otherwise, this pandemic promises to alter the structures, rhythms, and routines of various settings ranging from corporate institutions to K-12 education, and for an indefinite period (Steinfield et al., 2020). In weeks, we have witnessed school systems across the United States shift from bricks and mortar instruction to remote learning. Shuttering schools has caused parents and caregivers to become full-time educators striving to balance the competing demands of child-rearing, schooling, and employment (Harris, 2020; Russell et al., 2020). School districts, administrators, and teachers have had to orchestrate new and diverse learning environments and modalities such as distance learning and blended or hybrid models.

The current global health crisis has produced essential insights. Chief among them is that without cooperation and collaboration between institutions and within communities, we will be less able to 
curb the spread of the virus and serve the needs of children, youth, and their families, especially those facing adverse circumstances. Less visible to us in ordinary times, our individual and institutional interconnectedness across different types of industries-from healthcare to transportation to social services-is on full display during periods of uncertainty. It is clear that we have to adapt our traditional ways of working to address a mutual problem-one whose dimensions are complex, evolving, and not entirely known. Navigating both the immediate crisis and changes in the long run will require deliberate alliances and planned collaborations.

This paper explores how partnerships between school districts and geographically proximal universities may serve as a strategic resource that can be leveraged to help students learn during the COVID-19 pandemic. We demonstrate how partnerships that are motivated by an ethic of continuous improvement can overcome institutional boundaries (Gomez et al., 2020). These relationships provide stability and colleagueship and enable joint action in addressing shared and thorny problems (Bryk et al., 2015).

\section{SOCIAL CAPITAL AND PARTNERSHIPS}

Strategic partnerships are a form of social capital (Jamali et al., 2011). Researchers have demonstrated a robust association between social capital and community resilience in disaster response and positive recovery (e.g. Murphy 2007; ChamleeWright and Storr 2011; Melo Zurita et al., 2018). Although there is evidence that social resources matter for preparedness and recovery, governments and state agencies continue to spend more on physical resources while giving less consideration to strengthening social capital like building strategic partnerships (Aldrich and Meyer, 2015). In this way, our educational response to the pandemic is no different from local and national responses to disasters that have preceded COVID-19.

A brief scan of media coverage shows that the dominant educational response to this crisis has been about physical infrastructure, (e.g. broadband coverage). Many districts, for example, are purchasing and distributing large numbers of computers (Choi, 2020; Rauf, 2020). While computers are critical to response and recovery, leaders should pay greater attention to how school districts' social infrastructures aid their response to the pandemic. In the recent history of education, we see cases of technology acquisition that have fallen short of their aims due to the over-attention on the physical rather than the social infrastructure to support such efforts, (e.g. Lamb and Weiner, 2018). We suspect the same might be occurring with COVID-motivated acquisitions.

In this paper, we argue that partnership-a proxy for social infrastructure-can serve as a resource for educators to address the myriad challenges brought about by the pandemic. Specifically, we report on the activities of four partnerships between Local Education Agencies (LEAs) and Institutions of Higher Education (IHEs) in the Improvement Leadership Education and Development (iLEAD) Network (Velásquez et al., 2019). Guided by networked improvement science (Bryk et al., 2015),
iLEAD takes its raison d'être facilitating and sustaining mutually beneficial collaborations between postsecondary institutions and local districts and schools.

\section{MUTUALLY BENEFICIAL VS. TRANSACTIONAL PARTNERSHIPS BETWEEN LEAs AND IHEs}

Much of what occurs under the rubric of LEA-IHE partnerships has and continues to be transactional in the service provision sense. Whipple et al. (2010) refer to these transactional relationships as "me-centered." In contrast, collaborative institutional relationships are "we-centered." Me-centered relationships are about what I do for you, or you do for me. In comparison, we-centered relationships (what we describe here as mutually beneficial relationships are about what we engage in and accomplish together.

For instance, from a me-centered perspective, LEAs provide spaces and supervision for aspiring teacher candidates. University faculty offer professional development sessions or consulting arrangements to LEA staff to keep them abreast of technical and pedagogical developments in the field. By contrast, mutual benefit envisions partnership at a deeper, more institutionally entwined level. From a we-centered viewpoint, the LEA and IHE might work on a common problem of practice, such as ensuring that all students are proficient readers by the close of third grade. By pursuing a common aim, partners derive a net benefit from their joint efforts, and it is this benefit that fuels and sustains their work. In this third-grade reading example, LEAs might deepen staff's professional skills while IHE faculty advance understanding of practical reading theory; in short, both partners derive a common benefit from enhanced student achievement.

In comparison to mutually beneficial arrangements, transactional relationships may rely less on social trust and require less ongoing investment of time and money-suggesting that transactional relationships might be more transient. Yet, we suspect that organizational stressors, including the current pandemic, engender the types of multifaceted problems that persist and require more reliable connections. In this vein, Farrell et al. (2019) report that school district organizations with extensive communication pathways to their partners learn and thrive in complex task situations. As such, we theorize that collaborative, we-centered partnerships can serve as a viable approach to handling the uncertainties of a pandemic.

Still, it is important to stress that establishing and harnessing partnerships' benefits is not without its challenges (Brown and Poortman, 2018; Peel et al., 2002). Problems can arise in devoting enough time for capability building, creating shared governance and leadership, and developing equity and trust between participants, among other areas. Working in collaboration does not guarantee improved practice or outcomes. The work of iLEAD suggests that attention to the "how" of partnerships is vital. Its utility is precisely coupled to the extent to which the partnerships' social and activity structures enable its members to transcend traditional system boundaries and roles, develop 
shared meaning and language, and allow for the co-construction and refinement of ideas for usability. Attention to the mechanics of partnerships forces our attention to interaction among individuals and groups.

In what follows, we suggest that successful we-centered partnerships can lead organizations to deeper engagement in problems of practice, more equitable arrangements, and coherent strategies and activities. These attributes live in the micro-actions of organization members. We illustrate below how we use activity theory (Engeström, 2001) to discern how organizational and cross-organizational engagement, equity, and coherence might unfold in shared routines, language, and identity.

\section{ADDRESSING EDUCATIONAL ENGAGEMENT, EQUITY, AND COHERENCE}

Social capital is necessary for institutions to move beyond transactional relationships to ones characterized by mutualism (Chorzempa et al., 2010; Jamali et al., 2011). Examining iLEAD, we argue that shared commitment to continuous improvement principles, methods, and tools can form the basis for more productive and we-centered partnerships between LEAs and IHEs. We contend that three interrelated dilemmas that might be better handled by partnerships premised on shared activity and relational trust (Bryk and Schneider, 2002) are educational engagement, equity, and coherence.

\section{Engagement}

School systems strive to develop both academic and socialemotional skills among young people. However, shelter-inplace orders have challenged educators to monitor their students' attendance, participation, and development. These orders have also stripped away the social engagement that students experience within classrooms, cafeterias, and extracurricular opportunities (e.g. athletics, clubs). While social distancing measures can slow down the spread of infection, they may exacerbate the social isolation that some students experience and negatively affect their psychological well-being (Van Bavel et al., 2020). While the pandemic has diminished the usual structures for monitoring and engaging students, there are concerted efforts to increase participation virtually. How might leaders in LEAs and IHEs promote students' academic engagement and cultivate a sense of belonging during extended periods of at-home learning? How might they also support students' social and emotional health and development?

\section{Equity}

Long before COVID-19, school systems have struggled with ensuring equitable access to educational opportunities. With many efforts to enhance equity at the school site, (e.g. supplementary programs, instructional specialists), the sudden shift to at-home learning risks exacerbating the inequities school systems seek to ameliorate (García and Weiss, 2020). For instance, students from families with the most resources, (e.g. parents with flexible schedules, access to tutors) can support their children's academic growth. In contrast, students from families with the least resources fall further behind their more advantaged peers. What approaches might school leaders take to support, supplement, and structure at-home learning in ways that maintain a clear focus on educational equity, especially on meeting the needs of those furthest from opportunity? How might postsecondary institutions aid in this response?

\section{Coherence}

As attention to and use of online resources have skyrocketed, districts and schools have needed to cohere different strategies, tools, and approaches for shifting to online instruction (Reimers and Schleicher, 2020). Resources range from virtual curricula such as Eureka Math or Khan Academy to video platforms such as Zoom or Microsoft Teams to online learning systems such as Google Classroom and Schoology. We suspect the challenge of keeping the instructional program coherent (Newmann et al., 2001; Elmore et al., 2014) is compounded by stay-at-home orders that force teachers into additional hours of planning, preparation, and coordination. We also suspect that these orders make it more difficult for traditionally organized site-based teams to make decisions and monitor implementation. How might school and system leaders leverage these online resources without triggering tower-of-babel problems that accompany the uncoordinated deployment of competing virtual-learning supports?

\section{RESEARCH QUESTIONS}

Examining four iLEAD partnerships, we explore how wecentered approaches between LEAs and IHEs allow them to span their institutional boundaries to take a systems perspective on addressing the interrelated challenges of educational engagement, equity, and coherence. We explore the extent to which the activities engendered by an improvement orientation and the use of improvement science methods and tools shape routines and processes that enable shared practice and continuous learning. We investigate the characteristics of responses to the pandemic. We explore if partnerships can stay nimble in the face of uncertainty when they are user-centric, (i.e. privilege the experiences of students, teachers, and families), problem-focused, (i.e. avoid predetermined programs or solutions), and grounded in disciplined inquiry, (i.e. gather evidence to guide adaptations over time). Finally, we investigate the extent to which engagement in these types of district-university partnerships afford different perceptions of value and learning, both for its members and their institutions.

Three questions guide this study: (1) how do iLEAD partnerships utilize improvement science principles, methods, and tools to see and take up challenges related to educational engagement, equity, and coherence; (2) to what extent does improvement science, as shared activity and method of response to the pandemic, allow LEAs and IHEs to transcend institutional boundaries and attain ways of working for mutual benefit; and (3) how does engagement in iLEAD produce different types of value for its members and institutions? 
We organize the rest of the paper as follows. First, we provide an overview of networked improvement science and the goals and activities of the iLEAD network. Then, to guide our thinking on how the work of district-university partnerships might be disciplined, we draw from three strands of scholarship: (1) activity systems (Engeström, 2001); (2) boundary crossing and objects (Star and Griesemer, 1989; Akkermann and Bakker, 2011); and (3) value creation (Wenger et al., 2011). Next, we describe our data and analytic procedures, and present our findings with illustrative quotes to underscore emergent themes. Lastly, we conclude the paper by summarizing the advantages that mutually beneficial partnerships, rooted in continuous improvement, can bring in responding to the current and future crises.

\section{BACKGROUND}

\section{Networked Improvement Science and Communities}

Improvement science is rooted in management theory (Deming, 2018). It employs disciplined inquiry to solve specific problems of practice (Langley et al., 2009). From this perspective, a problemof-practice is "a persistent, contextualized, and specific issue embedded in the work of a professional practitioner, the addressing of which has the potential to result in improved understanding, experience, and outcomes" (Carnegie Project on the Education Doctorate (CPED), 2020). Improvement science grew in healthcare during the 1990s and has since spread to other sectors, including education (Lewis, 2015). For nearly a dozen years, the Carnegie Foundation for the Advancement of Teaching has been promoting a new relationship between research and practice through the use of improvement science enacted through networked improvement communities or NICs (Bryk et al., 2015; Russell et al., 2017).

Networked improvement communities are a flexible social learning model that allows members of a collaborative community to use improvement science to learn more, faster, together (Russell et al., 2017). Characterized as a scientific learning community, as well as a type of research-practice partnership (RPP) model (Coburn et al., 2013; Russell et al., 2017), NICs are made up of stakeholders from different backgrounds committed to solving common problems through shared theory and disciplined cycles of inquiry (Bryk et al., 2015; Khachatryan and Parkerson, 2020).

NICs have four distinguishing characteristics (Bryk et al., 2015). They are: (1) focused on a well-specified common aim; (2) guided by a deep understanding of the problem, the system that produces it, and a shared theory of improvement, (i.e. a collective sense of how to address the problem); (3) disciplined by the rigor of improvement science; and (4) coordinated to accelerate the development, testing, and refinement of interventions along with their more rapid diffusion out into the field and effective integration into varied educational contexts.

The Carnegie Foundation continues to test the NIC approach through its networks, (e.g. the Student Agency Improvement
Community; Zeiser et al., 2018) and many partners, including eight of California's largest districts (Gallagher and Cottingham, 2019). Although studies investigating the impact of networked improvement efforts are still emerging (Feygin et al., 2020), early evidence demonstrates promising outcomes. We see favorable results in areas that include college remediation (Edwards and Beattie, 2016; Yamada et al., 2018), early-grade literacy (Bradford et al., 2019), the retention of beginning teachers (Cornetto, 2015), mathematics instruction (Ell and Meisell, 2011), and college access (Aguilar et al., 2017).

As improvement science and networked improvement communities become more prevalent in education-as a result of increasing policy and local attention to continuous improvement (Klein, 2018) and growing financial support, (e.g. http://k12education.gatesfoundation.org/what-we-do/networksfor-school-improvement/)-better understanding of their ability to solve complex problems, including challenges brought about by COVID-19, become important (Feygin et al., 2020).

\section{The Improvement Leadership Education and Development (iLEAD) Network}

Improvement science continues to emerge as a core methodology and subject area of inquiry in educational leadership. Increasing numbers of colleges and universities are integrating continuous improvement into their capstone projects, dissertations, and certificate and degree programs (Perry and Zambo, 2018; Perry et al., 2020). However, preparing educational leaders with improvement capabilities requires a closer partnership between IHEs and LEAs (Grogan and Roberson, 2002; Young et al., 2002; Goldring and Simms, 2005; Miller et al., Shoop, 2007). To this end, the Carnegie Foundation launched the iLEAD network in 2017.

iLEAD believes the discipline of improvement science and its implementation through NICs are central to education leaders' methodological and conceptual preparation (Velásquez et al., 2019). iLEAD builds on the work of CPED, a consortium of 118 colleges and universities, often working in partnership with local school systems, seeking to transform the preparation of school and system leaders (Perry and Imig, 2008; Perry, 2015). Research demonstrates that district-university partnerships can help bridge theory and practice and prepare leaders to respond to district and regional challenges (e.g. Darling Hammond et al., 2007; Grogan et al., 2009; Young, 2010). iLEAD's theory of action argues that faculty in schools of education must partner with leaders of schools and systems in disciplined inquiry and practical and local problem-solving. By doing so, IHEs and LEAs can build practice-based evidence to solve local challenges and advance learning across the field to create impact at scale.

Currently, iLEAD consists of 11 district-university partnerships from across the country (see Supplementary Appendix A for a list of current members). These partnerships have demonstrated a willingness to build and sustain mutually beneficial partnerships, commitment to continuous improvement methods, and strong evidence of support from leadership and peers within and across their 


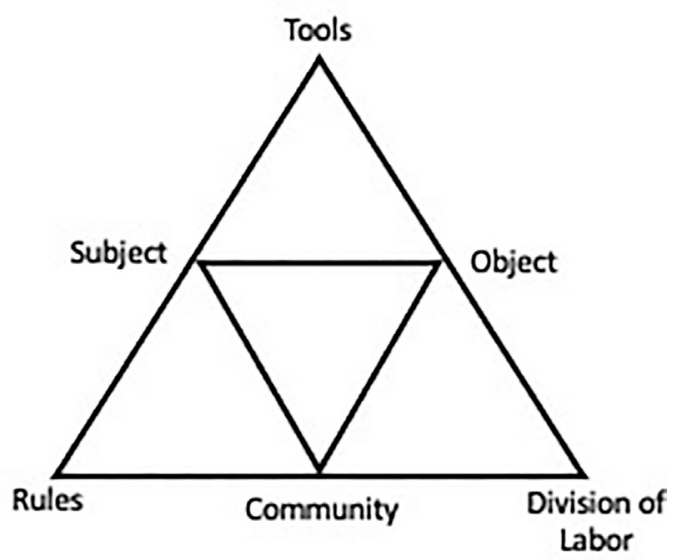

FIGURE 1 | A general model of an activity system (Engeström, 2001).

respective institutions (Velásquez et al., 2019). Since its launch, iLEAD has combined network-wide activities to enable crosspartnership learning with site-based efforts grounded in each partnership's objectives. For instance, at quarterly convenings, teams from different partnerships get together to discuss common dilemmas, share strategies, and engage in role-alike conversations and problem-solving. Teams also go back to their partnerships to integrate learning from others' work and chart future action.

Chief among iLEAD's accomplishments is its network-generated Developmental Progressions Framework, consisting of rubrics for IHEs, LEAs, and their partnerships (Supplementary Appendix B). Each rubric has different domains of work that get assessed as being at one of four levels: 1) exploring change ideas; 2) small change implementation; 3) integrating Improvement Science (IS)/NICs into core work; and 4) institutionalizing and sustaining the work. The Developmental Progressions represent a common language and communication "roadmap" that assists iLEAD partnerships in talking with one another, planning activities, and assessing progress along essential dimensions. In partnerships between complex organizations, shared communication tools and activities like the Developmental Progressions can generate opportunities to develop standard theory and practice, which, in turn, enables we-centered problem solving (Barge and Little, 2002; Whipple et al., 2010).

\section{The Convergence of Activity Systems, Boundary Objects, and Value Creation}

Establishing and sustaining mutually beneficial partnerships for continuous improvement is no easy feat (Brown and Poortman, 2018; Smedley, 2001). It requires both LEAs and IHEs to enact different kinds of organizational and social arrangements that disrupt how they typically pursue work (Borthwick et al., 2003). To guide our thinking on how the work of LEA-IHE partnerships might be disciplined, we draw from three strands of scholarship: (1) activity systems (Engeström, 2001); (2) boundary crossing and objects (Star and Griesemer, 1989; Akkermann and Bakker, 2011); and (3) value creation (Wenger et al., 2011).

\section{Activity Systems}

An activity system has a complex mediational structure that captures people's intellectual work in contextually bound ways. Engeström et al. (1999) define an activity system as a multi-voiced formation. It includes subject, tool, object, rules, community, distribution of labor, and outcomes (Figure 1). As participants of a particular activity, subjects adhere to formal or informal rules while using tools as resources to obtain their object or goal. Subjects belong to a particular community or group, and the division of labor is the shared responsibilities determined by that community. The outcome is the set of consequences the subject faces as a result of engaging in the activity. Different factors within an activity system can raise tension in the subject's effort to attain their goal. Further, the outcomes they face can either encourage or detract them from participating in future activities.

In Figure 2, we display conventional activity representations for LEAs and university schools of education. As these two different institutions engage in joint work, they will need to negotiate differences in functions, structures, reward systems, funding streams, and ethos, among other things. How they navigate these differences and participate in dialogic problem solving will depend on their ability to acquire expertise not only within the boundaries of their contexts and professions but also in others, including those that call for different, perhaps conflicting, mediating tools and patterns of social interaction (Tuomi-Gröhn et al., 2003). To explore how LEA and IHE actors' work may unfold across organizational lines, we appeal to the ideas of boundary crossing and objects (Star and Griesemer, 1989; Akkermann and Bakker, 2011).

\section{Boundary Crossing and Objects}

Engaging in collaborative work beyond one's role, institution, and discipline requires boundary crossing and objects. Akkermann and Bakker. (2011) define boundaries as sociocultural differences between practices leading to discontinuities in action or interaction. Boundaries are where the differences among people and the cultural systems they inhabit are put in relief. For an artifact to serve as a boundary object, it must be "... both plastic enough to adapt to local needs and constraints of the several parties employing them, yet robust enough to maintain a common identity across sites" (Star and Griesemer, 1989, p. 393).

In Figure 2, we reify this boundary space-the area between activity systems and boundary objects-as the commerce mechanism between the two. Consider, for example, Figure 2 is animated by the idea of tenure as a cultural artifact. Tenure and its meaning on either side of the LEA-IHE cultural boundary is very different; one needs boundary objects to allow cultural boundary-crossing. At the highest level, tenure can mean some form of employment security. Yet to explore its meaning across the boundary, actors from both sides will need to see how people work together, including the tools they use in each activity system to accomplish processes that result in a tenure judgment.

Likewise, if districts and universities are to stretch and connect their organizations, they will require boundary objects to help with sensemaking. In this case, one might imagine a new kind of representational dossier that stimulates local actors to create a common language of accomplishment. A type of resume or 


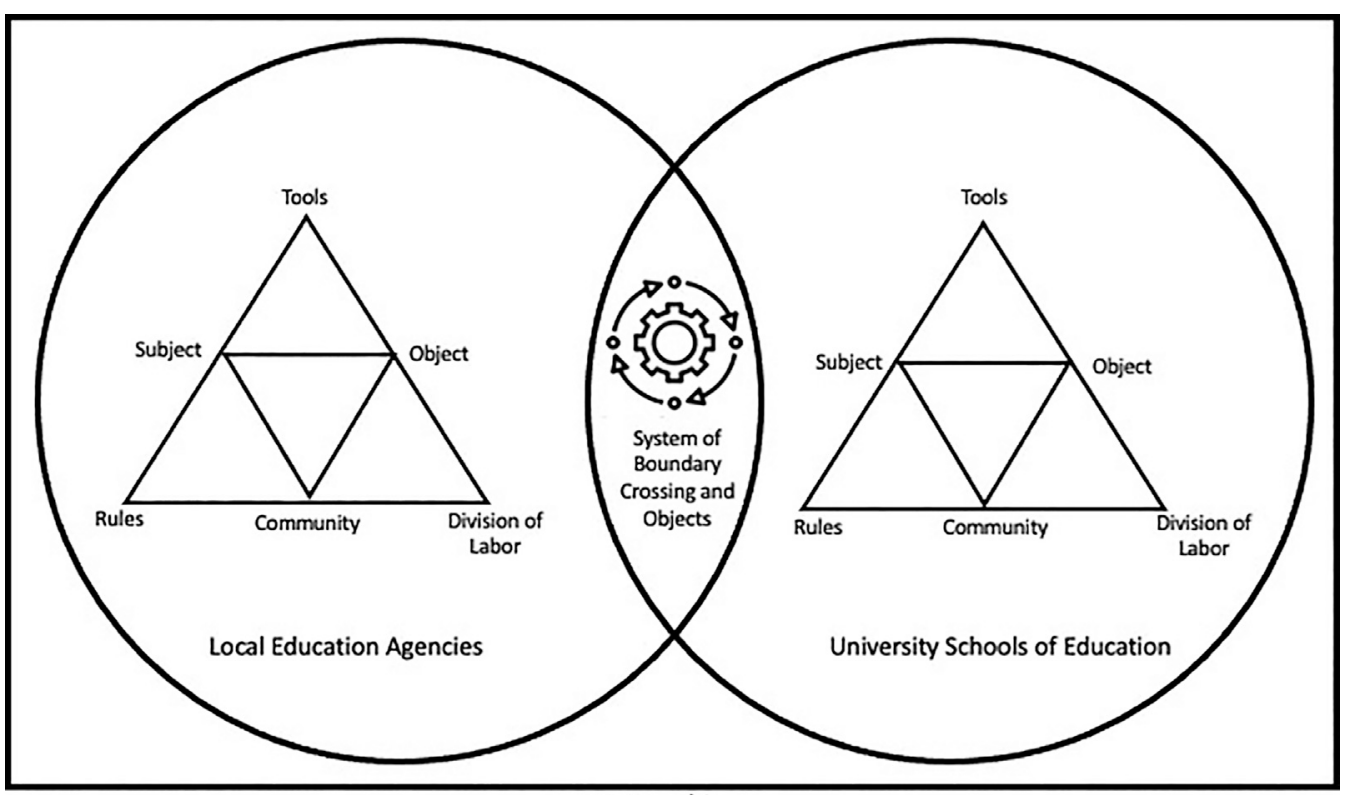

Partnership

FIGURE 2 | A system of boundary crossing and objects to discipline the activity systems of local education agencies and university schools of education in partnership.

personnel file might serve as a boundary object in that it helps people on either side of the cultural boundary understand what the other must do to achieve a form of employment security. Thus, collaboration at the intersection of different activity systems can lead to joint meaning-making and transformation of practices (Akkermann and Bakker, 2011).

Star and colleagues have suggested, (e.g. Star and Griesemer 1989; Star and Ruhleder, 1996; Star, 2010) that boundary crossing and boundary objects provide useful theoretical grounding. Accordingly, boundary objects can create collective action that is coherent and recognizable with an organization and between organizations. This joint recognizability, we suggest, lays the basis for a shared sense of value creation within and between organizations. To this point, researchers have paid less attention to the elements of district-university partnerships that might serve as boundary objects and how these, in turn, might support collaboration and communication. We contend that filling this knowledge gap can help the field understand how to enhance and create value-in this case, learning-that occurs within and across these LEA-IHE partnerships.

\section{Value Creation}

The possibility of social learning at multiple levels may attract people and organizations to networks like iLEAD. One level can refer to the learning to which individuals aspire. Another level is learning that occurs within a group of people who are part of a community; this learning is mediated through interactive processes shared by that group. What people learn can vary from the instrumental, such as acquiring a new skill or strategy, to the transformative (Argyris and Schon, 1996). Following Argyris and Schön, organizational actors engage in double-loop learning when they consider the assumptions about people and organizations that underlie their actions. Actors can also engage in triple loop learning, where the beliefs, values, and norms that undergird their personal, interpersonal, and organizational efforts are challenged.

We investigate social learning in iLEAD through the lens of value creation (Wenger et al., 2011). With communities or networks as the backdrop for social learning activities, Wenger and colleagues (2011) conceptualize value creation as "the value of learning enabled by community involvement and networking" (p. 7); this includes sharing ideas, co-constructing knowledge, and exchanging experiences. Wenger et al. identify five cycles of value creation: (1) immediate value (indicated by meaningful activities and interactions); (2) potential value (indicated by vital resources including knowledge capital); (3) applied value (indicated by the implementation of practices); (4) realized value (indicated by return on investment); and (5) reframing value (indicated by reconsidering frameworks and notions of success).

The value of learning in a network like iLEAD derives from the members' ability to forge shared purpose through common activity to enhance learning about, in this case, improvement leadership. This shared purpose and action, in turn, can foster "wecenteredness" through tools, strategies, and stories-all of which constitute learning resources for the community members to use as they work together to solve mutual problems (Wenger et al., 2011).

\section{METHOD}

We use the concepts of activity systems, boundary-crossing, boundary objects, and value creation to anchor a qualitative 
TABLE 1 | Panelists' roles and institutional affiliations.

\begin{tabular}{|c|c|c|}
\hline iLEAD partnership & Participant roles & Institution affiliation \\
\hline \multirow[t]{5}{*}{ New York City School Districts/Fordham University } & Executive Superintendent & Bronx Public Schools \\
\hline & Deputy Superintendent & Yonkers Public Schools \\
\hline & Academic Response Team Director & $\begin{array}{l}\text { New York City Department of } \\
\text { Education }\end{array}$ \\
\hline & Associate Professor, Educational Leadership, Administration, and Policy & $\begin{array}{l}\text { Fordham University School of } \\
\text { Education }\end{array}$ \\
\hline & Assistant Professor, Educational Leadership, Administration, and Policy & $\begin{array}{l}\text { Fordham University School of } \\
\text { Education }\end{array}$ \\
\hline \multirow{2}{*}{$\begin{array}{l}\text { Chesterfield County Public Schools/University of } \\
\text { Virginia }\end{array}$} & Director of School Improvement & Chesterfield County Public Schools \\
\hline & Associate Professor & University of Virginia \\
\hline \multirow{4}{*}{$\begin{array}{l}\text { Avondale Elementary School District/Arizona State } \\
\text { University }\end{array}$} & Superintendent & Avondale Elementary School District \\
\hline & Professor and Dean & Arizona State University \\
\hline & Associate Professor and Division Director of Teacher Preparation & Arizona State University \\
\hline & Co-Director for the Office of Clinical Experiences & Arizona State University \\
\hline \multirow{8}{*}{$\begin{array}{l}\text { Fairfax County Public Schools/George Mason } \\
\text { University }\end{array}$} & Executive Principal Region 1 & Fairfax County Public Schools \\
\hline & Middle School Language Arts Specialists, Instructional Service & Fairfax County Public Schools \\
\hline & Manager, Project Support Coach, Instructional Services & Fairfax County Public Schools \\
\hline & Secondary Language Arts Coordinator, Instructional Services & Fairfax County Public Schools \\
\hline & Provost and Executive Vice President & George Mason University \\
\hline & $\begin{array}{l}\text { Associate Professor and Director for the Division of Education Leadership } \\
\text { and Policy }\end{array}$ & George Mason University \\
\hline & Associate Professor, Education Leadership & George Mason University \\
\hline & Assistant Professor, Education Leadership & George Mason University \\
\hline
\end{tabular}

content analysis (Mayring, 2000) of four panel interviews that were part of a summer webinar series examining educational improvement science responses to COVID-19. ${ }^{1}$ For analytic purposes, we treated these webinars as publicly available panel interview data. Participants were invited because they reported that their organizations relied on iLEAD partnerships to negotiate the pandemic's early demands. Featuring partnerships from New York, Virginia, and Arizona, the discussions highlighted perspectives from LEA and IHE representatives and synthesized lessons on how members leveraged improvement science and their collaboration to respond to the dilemmas posed by the pandemic.

\section{Data}

We examined for emergent themes and patterns the transcripts and recordings from four panel interviews featuring the following partnerships: (1) New York City School Districts (Bronx and Yonkers)/Fordham University; (2) Chesterfield County Public Schools (CCPS)/University of Virginia (UVA); (3) Avondale Elementary School District/Arizona State University (ASU); and (4) Fairfax County Public Schools (FCPS)/George Mason University (GMU). Panelists included university faculty and leaders, as well as school and district administrators (Table 1);

The webinar series were sponsored by the Carnegie Foundation with support from the Gates Foundation. The series can be accessed here: https://www. carnegiefoundation.org/our-work/ilead/improvement-science-in-the-time-ofcovid-19/. Webinar participants were not aware the interviews would be used as data for the inquiry reported here. the same Carnegie Foundation executive moderated all of the discussions. All four partnerships have been active members of iLEAD since its launch in 2017, except the Avondale Elementary School District/ASU site which joined the network in 2018. The discussion with the New York City School Districts and Fordham University was pre-recorded; all others were conducted live using Zoom video conferencing, each drawing an audience of about 100 participants. Together, these discussions totaled $215 \mathrm{~min}$ and featured 19 speakers.

Each panel interview, which lasted approximately $50 \mathrm{~min}$, centered its discussion on a particular theme. For example, the discussion between New York institutions focused on using improvement science in educational settings characterized by persistent equity challenges, (e.g. economically disadvantaged neighborhoods and school systems). Similarly, the Chesterfield County/University of Virginia interview drew attention to their use of improvement science tools to tackle not only the dilemmas of educational engagement but also the systemic and persistent social and racial inequities brought into greater relief with the murder of George Floyd by Minneapolis police (Fernández, 2020). The Fairfax County Public Schools/George Mason University panelists highlighted their joint efforts to increase equity and engagement with students and families and teachers and school leaders involved in their networked improvement community on school improvement planning. Lastly, members of the Arizona partnership discussed how they worked together to address instructional and program coherence. They aimed to be improvement-minded and user-centered in their approach, and more intentional in breaking down classroom- and school-level silos in the Avondale Elementary School District. 


\section{Analysis}

Our analysis proceeded in three stages. First, we read and reread the transcripts and watched and re-watched the recordings of each interview to become as familiar as possible with the work of all four partnerships. Second, we kept track of salient patterns and themes that emerged when examining the iLEAD members' responses to questions about their use of improvement science to jointly address pandemic-related issues-namely, the challenges of educational engagement, equity, and coherence. Our conceptual frames enabled us to note evidence of improvement science thinking, tools, and activities, (e.g. the use of fishbone diagrams, conducting user-centered interviews). We also documented instances of boundary crossing and objects, as well as expressions of mutual benefit, value creation, and learning associated with work in the partnership and taking part in the iLEAD network activities. Finally, we applied axial coding to examine relations between emergent themes and reduce redundant themes into fewer categories (Merriam, 2002).

\section{Findings}

We found that district and school leaders in all four partnerships encountered various problems associated with educational engagement, equity, and coherence. These included technological and pedagogical challenges, progress monitoring and reporting concerns, as well as the problem of addressing students' physical, social, and emotional health, (e.g. recasting student nutrition programs to provide for home-schooled students). The data suggest that university partners' primary needs revolved around remaking clinical expectations for in-school assignments for interns, providing new ways for teacher candidates to acquire disciplinary knowledge, adding courses for building capacity in practicing teachers, and shifting the form and substance of graduate courses for school leaders. We observed that improvement science helped provide common language, facilitate joint action and strategy, and foster shared understanding. Also, we found that personal connections and relationships within each LEA-IHE partnership and across the iLEAD network served as a stabilizing force when dealing with the uncertainties of the pandemic. We report below emergent themes, and concepts found in the data and illustrate them using descriptive quotes and excerpts.

\section{Evidence of Improvement Science Principles, Methods, and Tools}

We identified different sets of commentary across the four partnerships describing the use of improvement science principles, methods, and tools to address the engagement, equity, and coherence problems arising from COVID-19. For example, one executive from Bronx Public Schools remarked how improvement science allowed them to explore the root causes of critical dilemmas in their system. She stated,

The pandemic heightened the crisis that we were all already leading through. And what this time has offered us is the opportunity to kind of pause and really be thoughtful about, how are we leveraging our tools? How are we leveraging the practices of improvement science, so that crisis leadership doesn't become the norm, the way in which we operate? Because there's so many different types of crisis facing our communities that the pandemic really just heightened for us. And so we've been really thinking a lot about how do we leverage improvement science to really identify what some of our real problems are, but also to tackle some smaller problems in order to address the bigger problems of our communities and our schools.

For others, improvement science allowed for new ways of tackling problems. A Chesterfield County school district leader, when describing their system's probable response to the pandemic before their partnership with UVA and following it, said,

I think that before we engaged in this improvement work and before we really engaged in this new strategic plan, we would have tried to get our users to fit into our system rather than shifting the system to support our users, to impact our users. So I think what this is allowing us to do, what we've learned to do is to be responsive and to try to not be as rigid based on, "Hey, this is what we have to offer, figure out where you fit in, get in where you fit in," as opposed to, but now really thinking about what is the impact of what we're doing? If it's not working, how can we pivot?

This respondent's university partner shared this sentiment of understanding and responding to the needs of stakeholders. He observed,

Pre-improvement, I think we would have focused on a more technical, rational approach. So we've got to go out and do a whole year-long investigation of what does Chesterfield need and what are the, you know, do a needs assessment and then do a sort of planning, a big Gantt chart of what do we need to do to redesign our courses and then implement the redesign and then, well, it's probably time to blow it up and do it again cause it doesn't work. So anyway, you get the idea, but the idea is that I'd like to think that we're more agile, that we're more listening more closely to what it is that colleagues are telling us.

One Fairfax County Public Schools leader also shared this improvement disposition-fully understanding the problem before enacting solutions. She commented how before improvement science, "I would have had 25,000 solutions, and I wouldn't have done any root-cause analysis whatsoever; that's how I would have approached it." Her counterpart at George Mason University agreed, noting that before her introduction to improvement science, she

Would have gone in, looked up some stuff, whatever that stuff may have been and created a resource and had 
never considered who was going to use the resource and would it work for them. So I think that for me has been very enlightening and eye opening.

A Yonkers Public Schools executive amplified these reflections of "before improvement, after improvement" by describing the use of improvement science to understand the scope of their COVID-19 challenges. She remarked,

So one thing we quickly realized was that we didn't have one problem, we had multiple problems of practice, situated within this whole COVID crisis. And each problem of practice required an intervention that was not necessarily, it was interdependent with the other interventions, right? And many of the people that we actually tapped to help solve the problems of practice were needed to solve multiple problems of practice.

Her colleague in Bronx Public Schools agreed and echoed these complexities stating that,

If we don't stop and really think about, one, which problem, which of the big, which parts of the big problems we're trying to solve and really go through a process to identify the unintended consequences connected to solving that problemm we will further deepen the inequities that exist in our community.

Persistent and worsening educational inequities concerned many iLEAD panelists. One administrator in the New York partnership observed how the schools in his network "were pretty uniquely set up to respond to the crisis," because improvement science was "sort of how we framed our entire work." He and his team had a practice of addressing context-relevant problems through "rapid, six to eight weeks cycles" of inquiry and testing. He commented how "we were able to pivot really quickly because of this," and "dig in and attack those points in a school system where inequities were brewing." This notion of ongoing learning was shared by a Chesterfield County leader who said,

Having had this experience and having folks in our school division who really seek to approach work from the learner stance, it really helped us to, even as we responded during the emergency side, we very early on went in with, "What are we learning from this as we go along"?

Lastly, Fairfax County Public school leaders pointed to the advantages of their social infrastructure and in using improvement science as a common language to begin addressing challenges and co-constructing strategies. One administrator commented,

We listen to each other, we listen to our students. And using this approach, it supports our shared understanding of the principles of practice that we're grappling with at any particular time. And when I think about communication, we use that shared language of improvement in our discussions that way, we're able to interpret what one another is doing, and it makes it easier for us to support one another, as well as get out of the way of one another.

\section{Boundary Crossing for Mutual Benefit}

Schools and universities in iLEAD were forced to confront the pandemic early and recast their partnership relationships to meet common needs, as well as the needs of their institutions. The relational trust built as a result of taking part in iLEAD, along with the shared activity of using improvement science as a means for learning, seemed to enable boundary crossing and collaboration. For instance, one faculty member at Fordham University observed how their program was a "success," and a significant departure from traditional designs because local problems informed the curriculum and content of practice. She stated,

We're using improvement science to really bring these authentic and incredibly important problems of practice to the center of their learning, that they're able to do their work with the support of their colleagues and faculty and new learnings as part of their studies, that's a signal to us that this, that we're doing something right this requires a dramatic culture shift, which arguably is a much bigger culture shift for higher education than it is for preK-12.

Leaders in Yonkers Public Schools described personnel with particular assignments and roles taking on new responsibilities to help address local problems, test change ideas in other areas of the district or system, and to do so in cooperation with different leaders and stakeholders. She remarked,

So, we quickly learned that we could tap central office administrators, parents, your clericals, your teachers, and they weren't necessarily serving in that role. They were serving where the need was so that we can have rapid cycles.

We noted similar descriptions made by Fairfax County leaders who suggested that COVID-19 affirmed an already existing practice of partnering with others outside one's role group and department. She said,

These interdepartmental relationships is the work that we were doing prior to the pandemic. For years within FCPS, it was understood and expected that you collaborate with people who were not in your particular content area. And because we had built those relationships already, it was seamless to then come together to then create something that was in the best interest of students and families. 
Throughout these interviews, partnerships were fundamental in addressing the myriad challenges brought about by the current health crisis. COVID-19 has underscored how "in these exceptional times the standard work processes are no longer holding" and that it is even more challenging to cultivate an "inquiry stance at a time of crisis." Fortunately, as one UVA professor observed, there was a long history of partnership between the university and district and that there were numerous UVA faculty also "working with Chesterfield for quite a while," who were "working inside the system" to build its capacity. He characterized the mutualistic learning happening between their institutions this way:

I think one of the richest things about our iLEAD partnership is this kind of intertwined capacity building of both. We're learning from Chesterfield about how to build courses that really respond to the leader's needs and the needs of a leadership pipeline, and they're learning from us about what kind of research we have about teaching teams and how teaching teams can help with culturally responsive teaching.

By trying to "build from the ground up leaders who are able to begin doing small cycles of inquiry in their schools on just the smallest kind of issues," it helped mobilize processes forward so that courses were formulated to support such functions. In this way, improvement science served as a bonding agent for these two institutions with different activity systems. These partners characterized their joint efforts as "an improvement sandwich," with the "bottom slice" being the types of issues and ways of preparing school leaders to address them. In contrast, the "top slice" represented the ways to foster and support this improvement work.

Like the CCPS/UVA partnership, the Avondale Elementary School District and university leaders in Arizona State University have had a long history of working together in ways that extended beyond institutional boundaries. They recognized that despite the pandemic, their "work needed to continue" and it was not realistic for them "to just go back and close up shop." Their subsequent efforts resulted in a new online resource at the university called the Sun Devil Learning Labs. ${ }^{2}$ Premised on a we-centered and continuous improvement ethos and developed in a "really short amount of time," this platform was designed to prototype new clinical practice opportunities for ASU teacher candidates in Avondale schools. Simultaneously, the Sun Devil Learning Labs aided the district in keeping their K-12 students engaged in instructionally coherent ways. As the superintendent noted, "We're in a continuous improvement model, we're going to continue to work by pulling people who have that expertise that we don't have, that distributed expertise and bringing it to the table." Although there were some challenges, these members acknowledged how their partnership was integral to developing Sun Devil Learning Lab. As one administrator recounted,

${ }^{2}$ For information about the Sun Devil Learning Labs: https://education.asu.edu/sdll
We brought all these people together this was happening in partnership, bringing that back to the content faculty so that they could think about how they needed to adapt. We were just moving in such a rapid pace that I think our communication was okay. Our communication could have probably been much stronger. We were able to build on the partnerships we had to mobilize quickly and I think we know well that we can depend on each other.

\section{Value Creation and Learning in Working Together}

Evidence suggests that engagement in iLEAD produced a renewed sense of the importance of partnership formation by both LEAs and IHEs and offered direction for deepening both systems' engagement in partnership. We found an acknowledgment of longstanding relationships before iLEAD and well-formed partnerships that served multiple purposes-some transactional and others for more mutualistic purposes. While variation exists among the iLEAD sites, we observed that years of participation in the network appeared to influence movement from initial identification and coordination of effort to new forms of learning and reflection and early stages of transformed practice (Akkermann and Bakker, 2011).

The pandemic was viewed by many as something very new in its demands on both partners and their partnerships. For instance, an administrator from Bronx Public Schools suggested that while COVID-19 was overwhelming, it offered an opportunity to see future crises in new ways, (i.e. that there was important learning to be had during this period). This insight makes visible a type of applied value (Wenger et al., 2011) in which stakeholders leverage improvement science thinking and tools to shift their practice. She remarked,

What we also learned with our students and working with our district partners that not only does it open up the severity of the crises for which we need to prepare our leaders better to address, but it also showed that there are opportunities for creativity. That we don't have to think about how do we do what we've always been doing within this new constraint. But the new constraint opens up a chance to work differently.

We observed new ways of boundary-crossing for mutual learning and benefit in different ways such as the joint identification of common problems of practice, and the redesign of graduate courses that both enrolled system leaders and sought their engagement in course redesign. The chief executive from George Mason University, for example, described the nearly 2 decades of partnership with Fairfax County as having "very similar objectives." He noted that while FCPS and GMU were two large complex and diverse organizations, they had "synergy," particularly now as COVID-19 challenged both of their institutions. He described the iLEAD partnership, and the broader collaboration between the university and the local schools and districts, as a "living laboratory" that tackles "big vexing problems" shared by Fairfax County and other northern Virginia school systems. He characterized the partnership in this way: 
We really think of ourselves as one and the same. And sometimes universities think themselves in a little bit different sphere than school districts and school districts think of universities as a little bit pejorative. And we haven't had to work hard to counteract that because there has been such mutual respect and the colleagueship has been based upon a commitment to collaboration.

We found this deference for one another's professional knowledge and expertise in the New York partnership also. One professor stated,

We have formed a cohort of mid-career professionals who want to pursue their doctorate.

And what we've learned is this crisis has created such enthusiasm for people who want to make a difference, who themselves have the passion that these issues are brought to the fore. It's really pushed us hard to say, "Okay, we're going to run a doctoral program with these people, we've really got to stay up with them, because they're going to run ahead of us. To be able to be part of a doctoral program that is going to take this on is humbling.

Another faculty member observed how this type of respect for school-level practitioners was rarely seen in higher education, whose traditions and activity structures tend to reward independent thinking and accomplishments. She said,

I think we have incredible, profound respect for our practice partners, we're very lucky to be able to work with them, and we bring ideas and questions to the table and design around them. I think we've been able to integrate improvement science in authentic ways. You know, it's also an ongoing process, obviously, there's plenty to learn and we continue to do so. But you know, that's I would argue opposite of the norm in higher education. And so to do this work and not have it be about teaching people about some tools and some processes and really have it be, become a space where great learning's happening about important real challenges, right, and action is happening as well requires a very different approach.

In addition to potential value (Wenger et al., 2011) or knowledge capital, (e.g. greater knowledge of improvement science), the data suggest that the relational bonds between iLEAD members also helped foster immediate value and "wecenteredness." The relational bonds may have played a role in minimizing professional isolation and fostering a level of trust and learning not usually seen in transactional or service-provision types of arrangements. For example, one CCPS administrator recounted a story of how she reached out to her university counterpart during the Black Lives Matter protests for strategic guidance:
When everything happened with George Floyd and the world was looking at our school saying, "So what you going to do"? My colleague who is our director of student equity and student support services, we're talking, we're like, "What we going to do"? And I said, "You know what? I have, I know someone who can help us think through this and think about how we should approach it". And we were able to call him and he was able to talk us through and really get us to thinking from this learner stance. She has since ran with it and we're doing some great things around training and professional development and really trying to prepare for the next year we're in unchartered territory and as much as we can learn from each other and what each of us are doing and how we're approaching this work and how we can be there for each other and with each other as we work for our kids, I think is what is going to help us get through this and really learn from this how we can better serve our kids.

\section{DISCUSSION}

Disasters are neither solely natural nor technological. Dynes. (1993) points out, disasters such as the current pandemic are social. While the precipitating factors in disasters are often natural or, in the case of COVID-19 biological, disasters as experienced by individuals and organizations are disruptions in the social order. The four iLEAD partnerships, whose responses to the current crisis we analyze for this study, experience the pandemic as a social phenomenon. For example, COVID-19 places economic disparities and access to learning resources in sharper relief. It has given renewed meaning to the question of what it takes to build engaging pedagogy for all students. COVID-19 has placed in full display the variation in learning contexts for many homebound students. LEAs, both within and outside of iLEAD, have asked themselves, what can we do when our students do not have a quiet place to work, or when families have limited devices for learning? It is perhaps not surprising that this issue, and others like it, would come to the fore. It redoubles attention to the meaning of systemic inequity and education's response to it.

Further, it is not surprising, faced with the pandemic and the concomitant inequity it brings, that LEAs and IHEs in iLEAD are wrestling with technology in new ways. Overnight, IT departments moved closer to the center stage of organizational life and LEAs are now facing novel student attendance and engagement challenges. Districts and schools are sorting out what newly collected data from remote learning settings reveal about genuine engagement vs. simple presence.

For all these partnerships, and the old and new dilemmas that accompany COVID-19, the grand challenge they face is maintaining the adults' well-being while focusing on students' social-emotional and academic needs. Our study suggests that we-centered partnerships may be attractive because they enable mutually beneficial social arrangements, which provide 
intellectual buffering-organizational slack-from the pandemic's onslaught on the social order in educational environments.

Bourgeois (1981), following Cyert and March. (1963), defines organizational slack as "cushion of actual or potential resources which allow an organization to adapt successfully to internal pressures for adjustment or to external pressures for change in policy, as well as to initiate changes in strategy with respect to the external environment" (p. 30). One way to see what mutual beneficial partnership arrangements bring to organizations is intellectually based organizational slack. That is, the partnerships give participants the space to think and strategize in disciplined ways. We briefly highlight below what some of this buffering protection looks based on our findings from the iLEAD partnerships.

\section{Avoiding Chaotic Responses}

The crucial charge for all public agencies, including universities and $\mathrm{K}-12$ systems, when hit by disasters is to keep their wits about them-not to become overwhelmed and prodded into ill-considered actions when faced with urgent disruption in their educational, social order. Organizations and their leaders induce even more chaos in already troubled waters by engaging in what Bryk et al. (2015) call "solutionists," the tendency to roll out organizational fixes before the problem is fully understood. The partnerships we explore here demonstrate agility to their response to COVID-19 while also maintaining a palpable reflectivity. For example, they do not hew toward shoehorning multiple old solutions into this unique and uncertain crisis. Given that the present partnerships are made up of "boundary-crossers," we suspect that an early tendency in mutually beneficial collaborations-when novel and complex challenges present themselves-is to venture across institutional borders and seek counsel.

From an organizational slack perspective (Bourgeois, 1981), the simple act of consultation aids in thinking things through more carefully and deliberately. It slows the all-too-normal tendency toward administrative and executive action before enough information is available for consideration. One behavior we frequently hear about in these interviews, which seem to define these partnerships as mutually beneficial, is the organizational propensity to listen. In light of such a predisposition, we see that when equity-based challenges present themselves, the presence of partnership offers the opportunity to listen to a novel interorganizational perspective that is, perhaps, not readily available intra-organizationally.

Our investigation of the partnerships' responses to the pandemic reveals a sense of attentiveness in light of chaotic educational conditions. In confronting the challenges before them, these LEAs and IHEs draw on their partnerships as a wellspring of relationships to meet the ever-changing demands. They lean on their social arrangements, which are premised on shared language, tools, and principles, to find stability and support to help lessen the social disorder that accompanies the pandemic.

\section{Problem Recognition and Response}

Like with other disasters (not of an education variety), we suggest that clear-headed recognition of, and response to, problems matters a great deal. We see these iLEAD partnerships bank on improvement science, and the disciplining set of resources and tools it offers, to create the intellectual space so they can be better at problem recognition and response. Among other things, we see partnerships use root-cause analysis, as well as Plan-Do-StudyAct (PDSA) cycles (Langley et al., 2009) to learn to continually adapt and coordinate collective action to address educational engagement, equity, and coherence.

Schools, such as those in Fairfax County, use root-cause analysis to allow LEA leaders to see how schools are experiencing the negative impacts from COVID-19 and then mount a quick response, (e.g. decreased attendance, low student engagement in virtual platforms). Likewise, we see some districts use these methods to conduct evidence-based pivoting in the provision of coherent online instruction learning.

The Sun Devil Learning Lab at Arizona State University has enabled partners to attend to teacher candidates' needs and local schools' needs. We see this response as particularly elegant and agile. Partners respond to the demands of teacher preparation changes while continuing to deliver instruction and service to both university and K-12 students. Given that the Sun Devil Learning Lab amounts to a rapid-testing facility, members of the Arizona partnership have been able to construct a much-needed space to think through ideas and potential solutions in a coordinated manner before acting. Coordination like this is critical if iLEAD partners are to respond to pandemic-induced changes to their systems in meaningful ways.

\section{The Power of Diverse Colleagueships}

iLEAD partners realize that one of the benefits of their social arrangements is the opportunity to slow down and learn from trusted colleagues. Trust and shared activity has enabled these colleagues to have access to critical thought partnership when advice is critically needed or when problems are too daunting for any one organization to tackle on its own (Brown and Poortman, 2018; Bryk and Schneider, 2002; Bryk et al., 2015). From an activity systems standpoint (Engeström, 2001), tools such as the Developmental Progressions Framework (Supplementary Appendix A) enable partners to move beyond institutional boundaries and understand what strengths they possess both inter and intra-organizationally (Akkermann and Bakker, 2011). Knowing one's partner's strengths and what skills and dispositions one can rely upon in moments of crisis is crucial and not arrived at quickly. Collaborative engagements like the ones we analyze here have supported LEAs and IHEs in building these essential understandings. With the benefit of the considered and diverse analysis, the partners determine when to deploy decisions and take action faster than they could without such a wellspring of relational knowledge. The partnerships allow them to work at a rate that makes sense for the problem at hand. Adding usable time in partnerships may, on the face of it, seem counterintuitive. On multiple occasions in the interviews, LEA and IHE leaders reported how colleagues who were not engaged in continuous improvement work cautioned them about the pandemic and its impact on their partnerships. Almost certainly, they would say, the COVID-19 crisis would short circuit their iLEAD work, the progress they have made toward the creation of mutually beneficial arrangements, as well as 
remove any time they had to devote to partnership development efforts. Yet these data suggest the opposite to be true.

The leaders whose work we report in this paper indicates that the pandemic accelerated the partnership's power. We think what others outside these arrangements fail to see is that shared language, principles, tools, and methods expand useful and diverse colleagues' sphere. It allows organizations to problem-solve with more confidence when they and their colleagues share common ground, problems, aims, and expectations; it also affords the creation different types of value and learning (Wenger et al., 2011).

Some scholars, such as Page (2008), suggest that diversity is a crucial resource in problem-solving and draw attention to what Page describes as idea diversity. Idea diversity (which is different from but related to demographic diversity) is an essential resource in an organization's ability to make progress in responding to vexing problems. When faced with uncertain situations, teams who are more cognitively diverse (in knowledge, perspectives, and ideas) deploy different heuristics to tackle the challenge at hand, thus resulting in accelerated learning and performance.

The Sun Devil Learning Lab, in all likelihood, could not have happened without a diverse colleagueship to draw upon. The colleagues across the social arrangements we analyze here understand that reciprocal partnerships are not time-sinks but, indeed, are time-amplifiers. Resources such as standard tools and language, (e.g. the Developmental Progressions Framework), along with the ability to see problems in a contextual and systems-minded way, may, paradoxically, add time to solving problems instead of constraining it.

\section{CONCLUSION}

While it is perhaps singular in the enormity of social disruptions, we can be sure other educational disasters will follow COVID-19. Whether realized or not, catalyzing we-centered, mutually beneficial partnerships, like those described here, are an exercise in social infrastructure emergency preparedness. Emergency preparedness is the assemblage of efforts that individuals make to keep social order before, during, and after an emergency. The present analysis suggests that the years these participants have spent building intellectual, social, and pedagogical relationships have paid organizational and community dividends in their ability to mitigate social disorder brought about by this pandemic.

On the one hand, the message to other organizations and communities from these four iLEAD partnerships' experiences is to underscore the social dimensions of educational disasters. On

\section{REFERENCES}

Aguilar, J., Nayfack, M., and Bush-Mecenas, S. (2017). Exploring improvement science in education: promoting college access in fresno unified school district. Stanford, CA, United States: Policy Analysis for California Education. Retrieved from: http://www.edpolicyinca.org/sites/default/ files/FUSD-continuous-improvement.pdf.

Akkermann, S. F., and Bakker, A. (2011). Learning at the boundary: an introduction. Int. J. Educ. Res. 50 (1), 1-5. doi:10.1016/j.ijer.2011.04.002 the other hand, present results indicate that deep collaborative work is needed to catalyze diverse colleagueships. All that they entail, including shared tools, common language, and developing boundary-crossing ability, is worth it. The work of the partnerships highlighted here suggests social infrastructures will pay practical preparedness returns in the next disaster that is undoubtedly to come.

\section{DATA AVAILABILITY STATEMENT}

Publicly available datasets were analyzed in this study. These data can be found here: https://www.carnegiefoundation.org/ourwork/ilead/improvement-science-in-the-time-of-covid-19/.

\section{ETHICS STATEMENT}

Ethical review and approval was not required for the study on human participants in accordance with the local legislation and institutional requirements. Written informed consent for participation was not required for this study in accordance with the national legislation and the institutional requirements.

\section{AUTHOR CONTRIBUTIONS}

The design and facilitation of the webinar discussions was led by AV. MB, LG, and DI conducted the qualitative content analysis. All authors contributed to the article and approved the submitted version.

\section{FUNDING}

The authors gratefully acknowledge the Gates Foundation (INV018875) for supporting the webinar discussions, and the Carnegie Corporation of New York for supporting this manuscript (Grant \#G-18-56221).

\section{SUPPLEMENTARY MATERIAL}

The Supplementary Material for this article can be found online at: https://www.frontiersin.org/articles/10.3389/feduc.2020.621361/ full\#supplementary-material.

Aldrich, D. P., and Meyer, M. A. (2015). Social capital and community resilience. Am. Behav. Sci. 59 (2), 254-269. doi:10.1177/0002764214550299

Argyris, C., and Schon, D. A. (1996). Organizational learning. vol. II: theory, method, and practice. Reading, MA, England: Addison-Wesley.

Barge, J. K., and Little, M. (2002). Dialogical wisdom, communicative, practice, and organizational life. Commun. Theor. 12 (4), 375-397. doi:10.1111/j.1468-2885. 2002.tb00275.x

Borthwick, A. C., Stirling, T., Nauman, A. D., and Cook, D. L. (2003). Achieving successful school-university collaboration. Urban Educ. 38 (3), 330-371. doi:10. $1177 / 0042085903038003003$ 
Bourgeois, L. J. (1981). On the measurement of organizational slack. Acad. Manag. Rev. 6 (1), 29-39. doi:10.2307/257138

Bradford, S., Fillers, B., McLeroy, M., McManus, R., and Wells, M. K. (2019). The story of the Tennessee early literacy network. Nashville, TN: Idealist. Retrieved from: www.tn.gov.

Brown, C., and Poortman, C. L. (2018). Networks for learning: Effective collaboration for teacher, school and system improvement. New York, NY: Routledge.

Bryk, A., and Schneider, B. (2002). Trust in schools: a core resource for improvement. NY, United States: Russell Sage Foundation.

Bryk, A. S., Gomez, L. M., Grunow, A., and LeMahieu, P. G. (2015). Learning to improve: how America's schools can get better at getting better. Cambridge, MA, United States: Harvard Education Press.

Carnegie Project on the Education Doctorate (CPED) (2020). The CPED Framework () [Website]. https://www.cpedinitiative.org/the-framework.

Chamlee-Wright, E., and Storr, V. H. (2011). Social capital as collective narratives and post-disaster community recovery. Socio. Rev. 59 (2), 266-282. doi:10.1111/ j.1467-954X.2011.02008.x

Choi, E. (2020). Remote learning without a laptop? Thousands could be stuck without devices due to shortage. Wall St. J.. https://www.wsj.com/articles/ laptop-shortage-hits-u-s-schools-as-thousands-face-online-learning-withoutdevice-11598434201

Chorzempa, B. F., Isabelle, A. D., and de Groot, C. (2010). Our quest for mutualism in university-school partnerships. Educ. Forum 74 (4), 306-317. doi:10.1080/ 00131725.2010.507084

Coburn, C. E., Penuel, W. R., and Geil, K. E. (2013). Research-practice partnerships: a strategy for leveraging research for educational improvement in school districts. New York, NY: William T. Grant Foundation. Retrieved from: https://rpp. wtgrantfoundation.org/wp-content/uploads/2019/10/Research-Practice-Partnershipsat-the-District-Level.pdf.

Cornetto, K. M. (2015). Building a teaching effectiveness network: coordinating support and feedback for beginning teachers in AISD schools. Austin, TX, United States: Department of Research and Evaluation Austin Independent School District. Retrieved from: https://www.austinisd.org/sites/default/files/drereports/14.77_Building_a_Teaching_Effectiveness_Network_Coordinating_ Support_And_Feedback_for_Beginning_Teachers_in_AISD_Schools.pdf.

Cyert, R. M., and March, J. G. (1963). A behavioral theory of the firm. Englewood Cliffs, NJ: Prentice-Hall.

Darling-Hammond, L., LaPointe, M., Meyerson, D., and Orr, M. (2007). Preparing school leaders for a changing world: lessons from exemplary leadership development programs. Stanford, CA, United States: Stanford Educational Leadership Institute Stanford University.

Deming, W. E. (2018). Out of the crisis. Cambridge, MA: MIT Press.

Dynes, R. R. (1993). Disaster reduction: the importance of adequate assumptions about social organization. Socio. Spectr. 13 (1), 175-192. doi:10.1080/02732173.1993.9982022

Edwards, A. R., and Beattie, R. L. (2016). Promoting student learning and productive persistence in developmental mathematics: research frameworks informing the Carnegie Pathways. NADE. Digest. 9 (1), 30-39Retrieved from: https://files.eric.ed.gov/fulltext/EJ1097458.pdf.

Ell, F., and Meisell, K. (2011). Working collaboratively to improve the learning and teaching of mathematics in a rural New Zealand community. Math. Educ. Res. J. 23, 169-187. doi:10.1007/s13394-011-0010-7

Elmore, R. F., Forman, M. L., Stosich, E. L., and Bocala, C. (2014). The internal coherence assessment Protocol and developmental framework: building the organizational capacity for instructional improvement in schools. Washington, DC, United States: SERP Institute.

Engeström, Y., Miettinen, R., and Punamäki, R. (1999). Perspectives on activity theory (Learning in doing: social, cognitive and computational perspectives. (Cambridge, United Kingdom: Cambridge University Press). doi:10.1017/CBO9780511812774

Engeström, Y. (2001). Expansive learning at work: toward an activity theoretical reconceptualization. J. Educ. Work 14 (1), 133-156. doi:10.1080/13639080020028747

Farrell, C. C., Coburn, C. E., and Chong, S. (2019). Under what conditions do school districts learn from external partners? The role of absorptive capacity. Am. Educ. Res. J. 56 (3), 955-994. doi:10.3102/0002831218808219

Fernández-Kelly, P. (2020). A sociological note on George Floyd's death and the pandemic. Items: Insights from the Social Sciences. https://items.ssrc.org/covid19-and-the-social-sciences/society-after-pandemic/a-sociological-note-on-georgefloyds-death-and-the-pandemic/.
Feygin, A., Nolan, L., Hickling, A., and Friedman, L. (2020). Evidence for networked improvement communities. Washington, DC, United States: American Institutes for Research. Retrieved from: https://www.air.org/sites/default/ files/NIC-Systematic-Review-Report-123019-Jan-2020.pdf.

Gallagher, A., and Cottingham, B. (2019). Learning and practicing continuous improvement: lessons from the CORE districts. Stanford, CA: Policy Analysis for California Education. Retrieved from: https://www.edpolicyinca.org/publications/ learning-and-practicing-continuous-improvement-lessons-core-districts.

García, E., and Weiss, E. (2020). COVID-19 and student performance, equity, and US education policy: lessons from pre-pandemic research to inform relief, recovery, and rebuilding. Washington, DC, United States: Economic Policy Institute. Retrieved from: https://www.epi.org/publication/the-consequences-of-the-covid-19pandemic-for-education-performance-and-equity-in-the-united-states-what-canwe-learn-from-pre-pandemic-research-to-inform-relief-recovery-and-rebuilding/.

Goldring, E., and Simms, P. (2005). Modeling creative and courageous school leadership through district-community-university partnerships. Educ. Pol. 19 (1), 223-249. doi:10.1177/0895904804270777

Gomez, L., Biag, M., and Imig, D. (2020). "Learning at the boundaries: reconsidering university-district partnerships for educational leadership," Editors N. Suad Nasir, C. Lee, and R. Pea. Handbook of the cultural foundations of learning (New York, NY: Routledge), 365-384.

Grogan, M., and Roberson, S. (2002). Developing a new generation of educational leaders by capitalizing on partnership. Int. J. Educ. Manag. 16 (7), 314-318. doi:10.1108/09513540210448068

Grogan, M., Bredeson, P. V., Sherman, W. H., Preis, S., and Beaty, D. M. (2009). "The design and delivery of leadership preparation,". Editors M.D. Young, G.G. Crow, J. Murphy, and R.T. Ogawa. Handbook of research on the education of school leaders (New York, NY: Routledge), 395-416.

Harris, E. A. (2020). "It was just too much": how remote learning is breaking parents. The New York Times. https://www.nytimes.com/2020/04/27/nyregion/ coronavirus-homeschoolingparents.html.

Jamali, D., Yianni, M., and Abdallah, H. (2011). Strategic partnerships, social capital and innovation: accounting for social alliance innovation. Bus. Ethics Eur. Rev. 20 (4), 375-391. doi:10.1111/j.1467-8608.2011.01621.x

Khachatryan, E., and Parkerson, E. (2020). Moving teachers to the center of school improvement. Phi Delta Kappan 101 (6), 29-34Retrieved from: https://kappanonline. org/moving-teachers-center-school-improvement-khachatryan-parkerson/.

Klein, A. (2018). "Continuous improvement' model woven into state ESSA plans." EdWeek. Retrieved from:https://www.edweek.org/ew/articles/2018/05/07/ continuous-improvement-model-woven-into-state-essa.html

Kumar, J. (2020). Biological disaster management. IJTRS 5 (2), 5-10. doi:10.30780/ IJTRS.V05.I07.002

Lamb, A. J., and Weiner, J. M. (2018). Institutional factors in iPad rollout, adoption, and implementation: isomorphism and the case of the Los Angeles Unified School District's iPad initiative. Int. J. Educ. Math. Sci. Technol. 6 (2), 136-154. doi:10.18404/ijemst.408936

Langley, G. J., Moen, R., Nolan, K. M., Nolan, T. W., Normal, C. L., and Provost, L. P. (2009). The improvement guide: a practical approach to enhancing organizational performance. 2nd Edn. San Francisco, CA, United States: Jossey-Bass.

Lewis, C. (2015). What is improvement science: do we need it in education?. Educ. Res. 44 (1), 54-61. doi:10.3102/0013189X15570388

Mayring, P. (2000). Qualitative content analysis. Forum Qual. Soc. Res. 1 (2), 21, Retrieved from: https://www.qualitative-research.net/index.php/fqs/index. doi:10.17169/fqs-1.2.1089

Merriam, S. B. (2002). Introduction to qualitative research. In S. B. Merriam (Ed.), Qualitative research in practice: Examples for discussion and analysis. San Francisco, CA: Jossey Bass.

Melo Zurita, M. L., Cook, B., Thomsen, D. C., Munro, P. G., Smith, T. F., and Gallina, J. (2018). Living with disasters: social capital for disaster governance. Disasters 42 (3), 571-589. doi:10.1111/disa.12257

Miller, T. N., Devin, M., and Shoop, R. J. (2007). Closing the leadership gap: how district and university partnerships shape effective school leaders. Thousand Oaks, CA: Corwin Press.

Murphy, B. L. (2007). Locating social capital in resilient community-level emergency management. Nat. Hazards 41 (2), 297-315. doi:10.1007/s11069-006-9037-6

Newmann, F. M., Smith, B., Allensworth, E., and Bryk, A. S. (2001). Instructional program coherence: what it is and why it should guide school improvement policy. Educ. Eval. Pol. Anal. 23 (4), 297-321. doi:10.3102/01623737023004297 
Page, S. E. (2008). The difference: how the power of diversity creates better groups, firms, schools, and societies-new edition. Princeton, NJ: Princeton University Press.

Peel, H. A., Peel, B. B., and Baker, M. E. (2002). School/university partnerships: a viable model. Int. J. Educ. Manag. 16 (7), 319-325. doi:10.1108/09513540210448077

Perry, J. A., and Imig, D. G. (2008). A stewardship of practice in education. Change 40 (6), 42-49. doi:10.3200/CHNG.40.6.42-49

Perry, J. A. (2015). The Carnegie project on the education doctorate. Change 47 (3), 56-61. doi:10.1080/00091383.2015.1040712

Perry, J. A., and Zambo, D. (2018). Themed section of Impacting Education focused on CPED's principle. Impacting Educ. J. Transforming Prof. Pract. 3 (2), 17-23. doi:10.5195/ie.2018.89

Perry, J. A., Zambo, D., and Crow, R. (2020). The improvement science dissertation in practice: a guide for faculty, committee members, and their students. Gorham, ME, United States: Myers Education Press.

Rauf, D. S. (2020). Coronavirus pushes schools closer to a computer for every student. Education Week:https://www.edweek.org/ew/articles/2020/06/03/coronaviruspushes-schools-closer-to-a-computer.html.

Reimers, F. M., and Schleicher, A. (2020). A framework to guide an education response to the COVID-19 Pandemic of 2020. Paris, France: OECD. Retrieved from: https://oecd.dam-broadcast.com/pm_7379_126_126988-t63lxosohs.pdf.

Russell, J. L., Bryk, A. S., Dolle, J., Gomez, L. M., LeMahieu, P., and Grunow, A. (2017). A framework for the initiation of networked improvement communities. Teach. Coll. Rec. 119 (7), 1-36.

Russell, B. S., Hutchison, M., Tambling, R., Tomkunas, A. J., and Horton, A. L. (2020). Initial challenges of caregiving during COVID-19: caregiver burden, mental health, and the parent-child relationship. Child Psychiatr. Hum. Dev. 51 (5), 671-682. doi:10.1007/s10578-020-01037-x

Smedley, L. (2001). Impediments to partnership. A literature review of schooluniversity links. Teachers Teaching. 7 (2), 189-209. doi:10.1080/ 13540600120054973

Star, S. L., and Griesemer, J. R. (1989). Institutional ecology, translations and boundary objects: amateurs and professionals in Berkeley's Museum of Vertebrate Zoology, 1907-39. Soc. Stud. Sci. 19 (3), 387-420Retrieved from: https://images-insite.sgp1.digitaloceanspaces.com/dunia_buku/koleksi-bukulainnya/institutional-ecology-translations-and-boundary-objects-amateurspdfdrivecom-42531582402862.pdf. doi:10.1177/030631289019003001

Star, S. L., and Ruhleder, K. (1996). Steps toward an ecology of infrastructure: design and access for large information spaces. Inf. Syst. Res. 7 (1), 111-134. doi:10.1287/isre.7.1.111

Star, S. L. (2010). This is not a boundary-object: reflections on the origin of the concept. Revue d'anthropologie des connaissances 4 (1), 18-35. doi:10.3917/rac. 009.0018

Steinfield, J. (2020). Unprepared: America in the time of coronavirus. New York, NY: Bloomsbury Publishers.
Tuomi-Gröhn, T., Engeström, Y., and Young, M. (2003). "From transfer to boundary-crossing between school and work as a tool for developing vocational education: an introduction," Between school and work: new perspectives on transfer and boundary-crossing. Editors T. Tuomi-Gröhn and Y. Engeström (Amsterdam, Netherlands: Pergamon Press), 1-15.

Van Bavel, J. J., Baicker, K., Boggio, P. S., Capraro, V., Cichocka, A., Cikara, M., and Drury, J. (2020). Using social and behavioural science to support COVID-19 pandemic response. Nat. Hum. Behav. 4 (6), 460-471. doi:10.1038/s41562-0200884-z

Velásquez, C., Biag, M., Gomez, L., and Imig, D. (2019). Partnering for leadership development and continuous improvement: carnegie's improvement leadership education and development network. AERA learning and teaching in educational leadership newsletter.

Wenger, E., Trayner, B., and De Laat, M. (2011). Promoting and assessing value creation in communities and networks: a conceptual framework, 20. Netherlands: Ruud de Moor Centrum. Retrieved from: https://wengertrayner.com/documents/Wenger_Trayner_DeLaat_Value_creation.pdf.

Whipple, J. M., Lynch, D. F., and Nyaga, G. N. (2010). A buyer's perspective on collaborative versus transactional relationships. Ind. Market. Manag. 39 (3), 507-518. doi:10.1016/j.indmarman.2008.11.008

Yamada, H., Bohannon, A. X., Grunow, A., and Thorn, C. A. (2018). Assessing the effectiveness of Quantway ${ }^{\circledR}$ : a multilevel model with propensity score matching. Community Coll. Rev. 46 (3), 257-287. doi:10.1177/0091552118771754

Young, M. D., Petersen, G. J., and Short, P. M. (2002). The complexity of substantive reform: a call for interdependence among key stakeholders. Educ. Adm. Q. 38 (2), 137-175. doi:10.1177/0013161X02382003

Young, M. (2010). From the director: the promise of university-district partnerships. UCEA Rev. 51 (1), 1-3Retrieved from: https://education. illinoisstate.edu/downloads/isl/sreb-workshop/the-promise-winter-2010.pdf.

Zeiser, K., Scholz, C., and Cirks, V. (2018). Maximizing student agency implementing and measuring student-centered learning practices. Washington, DC, United States: American Institutes of Research. Retrieved from: https://files.eric.ed.gov/fulltext/ED592084.pdf.

Conflict of Interest: The authors declare that the research was conducted in the absence of any commercial or financial relationships that could be construed as a potential conflict of interest.

Copyright (๑ 2021 Biag, Gomez, Imig and Vasudeva. This is an open-access article distributed under the terms of the Creative Commons Attribution License (CC BY). The use, distribution or reproduction in other forums is permitted, provided the original author(s) and the copyright owner(s) are credited and that the original publication in this journal is cited, in accordance with accepted academic practice. No use, distribution or reproduction is permitted which does not comply with these terms. 